\title{
Planting coffee and take care of forest: A case study on coffee cultivation in the forest carried out among people of Palintang, Highland of Bandung, West Java, Indonesia
}

\author{
BUDIAWATI SUPANGKAT ISKANDAR ${ }^{1}$, JOHAN ISKANDAR ${ }^{2}$, RUHYAT PARTASASMITA ${ }^{2, ~}$, \\ RAHMAN LATIF ALFIAN ${ }^{3}$ \\ ${ }^{1}$ Department of Anthropology, Faculty of Social and Political Science, Universitas Padjadjaran. Jl. Raya Bandung-Sumedang Km21, Jatinangor, \\ Sumedang 45363, West Java, Indonesia \\ ${ }^{2}$ Department of Biology, Faculty of Mathematics and Natural Sciences, Universitas Padjadjaran. Jl. Raya Bandung-Sumedang Km. 21, Jatinangor, \\ Sumedang 45363, West Java, Indonesia. Tel./fax.: +62-284-288828. `email: ruhyat.partasasmita@unpad.ac.id; rp2010rikkyo@gmail.com \\ ${ }^{3}$ Postgraduate Program, Department of Anthropology, Faculty of Social and Political Science, Universitas Padjadjaran. Jl. Raya Bandung-Sumedang \\ Km21, Jatinangor, Sumedang 45363, West Java, Indonesia
}

Manuscript received: 25 September 2018. Revision accepted: 4 November 2018.

\begin{abstract}
Iskandar BS, Iskandar J, Partasasmita R, Alfian RL. 2018. Planting coffee and take care of forest: A case study on coffee cultivation in the forest carried out among people of Palintang, Highland of Bandung, West Java, Indonesia. Biodiversitas 19: 21832195. People of Palintang hamlet of highland of Bandung, West Java have interacted with the forest ecosystem for a long time. In the past, initially, they cultivated forest by practicing swidden farming system (ngahuma) based on the traditional ecological knowledge which strongly embedded with local culture. During the Dutch colonial, some people of Palintang involved as the laborer of various activities of the culture system in the forest. After Indonesian independence, Palintang people have participated as laborers in various activities in the mixed-cropping (tumpangsari) program of the Forestry Service (Dinas Kehutan) and later on the State Forestry Corporation (Perhutani). In 1983, the tumpangsari program was formally prohibited because of its potency to cause environmental destructions, but some people of Palintang have continuously planted vegetables in the forest to get household income. Although the cultivation of vegetables in the forest provided some economic benefits, however, some forest destruction and environmental destructions, including soil erosion, landslide, pesticide pollution have not been inevitable. In 2005 Perhutani launched the management of forest resources together with the community (PHBM=Pengelolaan Sumber Daya Hutan Bersama Masyarakat), mainly by introducing Arabica coffee (Coffea arabica L) to be planted in the pine (Pinus merkusii Jungh) forest to replace the farming of vegetables in the forest. This paper elucidates the historical process of introduction of Arabica coffee in the pine forest of Palintang through the PHBM program of Perhutani. The method used in this study was qualitative with descriptive analysis. Some techniques, namely observation, semi-structured interview, and participant observation were applied in this study. The result of the study showed that the introduction of coffee had been adopted by rural people of Palintang through a long time process with learning by doing. It was revealed that several factors caused the residents accepting coffee plants to be cultivated on forest land, i.e., coffee plants were only once planted in the past in their area, and the area is suitable for coffee cultivation. Besides, coffee has been considered to be planted and give economic benefits; and was initially planted in combination with annual crops, including vegetables, so that before the coffee is produced, the rural people can still produce annual agricultural products such as vegetable crops. However, when the coffee started to produce, time allocation, labor, and capital were more emphasized on the cultivation of coffee instead of vegetable crops; thus, cultivation of vegetables is gradually reduced and even stopped. The forest ecosystem of Palintang can be utilized and maintained by the rural community as indicated by their perception of the forest ecosystem. Thus, people of Palintang have increased awareness that they want to protect forest areas after their coffee cultivation in the forest area provides economic benefits to them.
\end{abstract}

Keywords: Coffee, farmers, forest, Palintang, PHBM program, West Java

\section{INTRODUCTION}

From environmental history or ecological history, forest in West Java has changed over time due to many factors, including population growth and government policy. Since the early nineteenth century onward, since population density has increased, more permanent agroecosystem types including wet rice field (sawah), homegarden (pekarangan), mixed-perennial crops (kebun campuran), and garden (kebun) have evolutionally developed from conversion of forest to create agroecosystem types (Soemarwoto 1984; Iskandar and Iskandar 2011; Iskandar et al. 2016). Forests in West Java have also changed over time caused by the government policy. For example, since the Dutch colonial, forests of West Java have been widely opened and cultivated by commercial wood plants and crops, including teak, cinnamon, tea, cinchona, tobacco, coffee, and pepper (Geertz 1963; Elson 1994; Iskandar 1998; Muhsin 2017; Iskandar et al. 2017; Kurniawan et al. 2018; Fineso 2018). Post-colonial period, most forests in West Java have been managed by the Forestry Service (Dinas Kehutanan), and in 1972 it was changed to the State Forestry Corporation (Perhutani). Since the early 1970s, the Perhutani introduced management program called the prosperity approach program implemented in the development of mixed-cropping (tumpangsari) program 
which was initially introduced in 1895 (Perum Perhutani 1994). Based on the tumpangsari program, rural communities have been involved as laborers in various activities of forestry programs, including land preparation, wood seedling preparation, and wood trees maintenance (Kartasubrata 1986). In the tumpangsari program, rural communities have also been allowed to plan annual crops (palawija), including beans, corn, cassava and cucumber in the forest. Theoretically, the tumpangsari programs could provide some benefits for both Perhutani and rural community. For example, the rural communities involved in the tumpangsari program may get jobs and produce annual crops planted in the forest to fulfill the household needs. Meanwhile, the Perhutani obtained cheap labor from rural communities involved in various activities, including land preparation, nursery and seedling preparation, and planting plants in the forestry program. However, the tumpangsari program failed to maintain and to rehabilitate forest ecosystem.

In many cases, the young wood plants such as mahogany, teak, and pine failed to grow in the forest rehabilitation programs, but the cultivation of annual crops carried out by rural people cannot be controlled. For example, since the upland condition of West Java that is suitable for cultivation of vegetables, many upland areas of this region, including Palintang of North Bandung have been predominantly planted with vegetable crops such as cabbage, potato, and tomato in the pine forest. Although the cultivation of vegetables in the forest provided economic benefits, some environmental problems including soil erosion and pesticide pollution are not inevitable (Iskandar et al. 2017).

To improve management of forest production in Java, in 2001 Perhutani launched the Management of Forest Resources with the Community (PHBM=Pengelolaan Sumberdaya Hutan Bersama Masyarakat). Based on the Perhutani (the Forestry Minister's Decree No 136 / KPTS / 2001), PHBM program is known as a forest management system jointly carried out by Perhutani and forest village communities with stakeholders so that the common interest in achieving sustainability of the functions and benefits of forest resources can be realized optimally and proportionally. In the realization of the PHBM program, the Perhutani has introduced Arabica coffee (Coffea arabica L) to be farmed in mixture cropping with Eucalyptus trees in the forest of Pangalengan, South Bandung in the early 2000s (Widaningsih 2016). Similarly, the forest of Rancakalong, Sumedang, has also been farmed by Arabica coffee integrated with pine (Pinus merkusii) trees through the PHBM program in 2007 (Hasan et al. 2018).

Like Pangalengan and Rancakalong, the Arabica coffee has also been introduced by Perhutani in Palintang since 2005. Actually, on the basis of ecological history, the forest of Palintang of Manglayang complex has been planted with various commercial plants including tobacco, quinine, tea, and coffee since the Dutch colonial, and local communities have been involved as laborers in multiple activities in the forestry program. Indeed, in the post-colonial, local communities of Palintang have been engaged as laborers in the tumpangsari program of the Forestry Service (Dinas
Kehutanan) and later on the State Forestry Corporation (Perhutani) (Iskandar et al. 2007). Therefore, the people of Palintang, particularly the old generation, have had experience in planting crops in the forest. The people of Palintang have lately adopted introduction of Arabica coffee plants through PHBM program in Palintang forest of Perhutani aiming at replacing the farming vegetables with coffee plants to provide a good income for the local community and also to protect the pine forest.

This paper elucidates the ecological-historical process of introduction of Arabica coffee in the pine forest of Palintang Hamlet, Cipanjalu Village, Cilengkrang Subdistrict, Bandung District, West Java, Indonesia through the PHBM program of Perhutani. Three aspects will be elucidated in this paper, namely the ecological history of coffee introduction in the forest; cultivation of coffee trees in the forest; and some benefits of coffee cultivation in the forest of Palintang.

\section{MATERIALS AND METHODS}

\section{Study site}

The study was carried out in Palintang hamlet that is an enclave hamlet in the pine forest of Perhutani. Administratively, Palintang hamlet is one of the hamlets of Cipanjalu Village, Cilengkrang Sub-district, Bandung District, West Java, Indonesia (Figure 1).

The Palintang hamlet has located approximately $8 \mathrm{~km}$ from traditional market of Ujung Berung that is a center of the Ujung Berung Sub-district of Bandung Municipality, West Java. To reach the Palintang from Ujung Berung, we can use a vehicle through a good asphalt road, but it is rather narrow (Figure 2.A). The Palintang is situated directly adjacent to the Perhutani pine forest area (Figure 2.B). This area includes the northern Bandung highland at approximately $1,400 \mathrm{~m}$ above sea level. Geographically, Palintang is a hilly area which covers the base of Manglayang mountain. The land use of Palintang is devoted to settlement and homegarden, fishpond, and garden. The air temperature of Palintang hamlet is recorded approximately $28^{\circ}-29^{\circ} \mathrm{C}$ during the day, while at night it is colder.

Since Palintang is located in the upland area surrounded by forest, the people of Palintang have culturally adapted to the local environment, forest ecosystem (Iskandar 2017; 2018). Most people of Palintang have a livelihood as farmers. They cultivate various non-crops in the homegarden, garden, and forest garden, but have never been involved in farming wet rice field (sawah) system as there was no sawah in Palintang. Since 1980s, most Palintang people have been engaged in agroecosystems of farming vegetables, potato (Solanum tuberosum L), cabbage (Brassica oleracea L var capitala), Indian mustard (Brassica juncea (L) Czern), pablano papper (Capsicum annuum L.var Grosum), tomato (Lycopersicon esculentum Mill), and Welsh onion (Allium fistulosum L), and farming coffee (in the pine forest ecosystem (Iskandar et al. 2016). Some people have also engaged in trading, and civil servants and private employees. Vegetable farmers have been mainly selling various vegetable productions to local 
middlemen or intermediaries who usually come to their village, and also to traditional markets of Bandung, mainly traditional market of Ujung Berung located not far from their hamlet (Iskandar et al. 2018). Vegetable farmers are mostly members of farmer groups, and some of them are middlemen. Also, some of the individual farmers have been involved in both farming and petty trading of the smallscale household economy system.

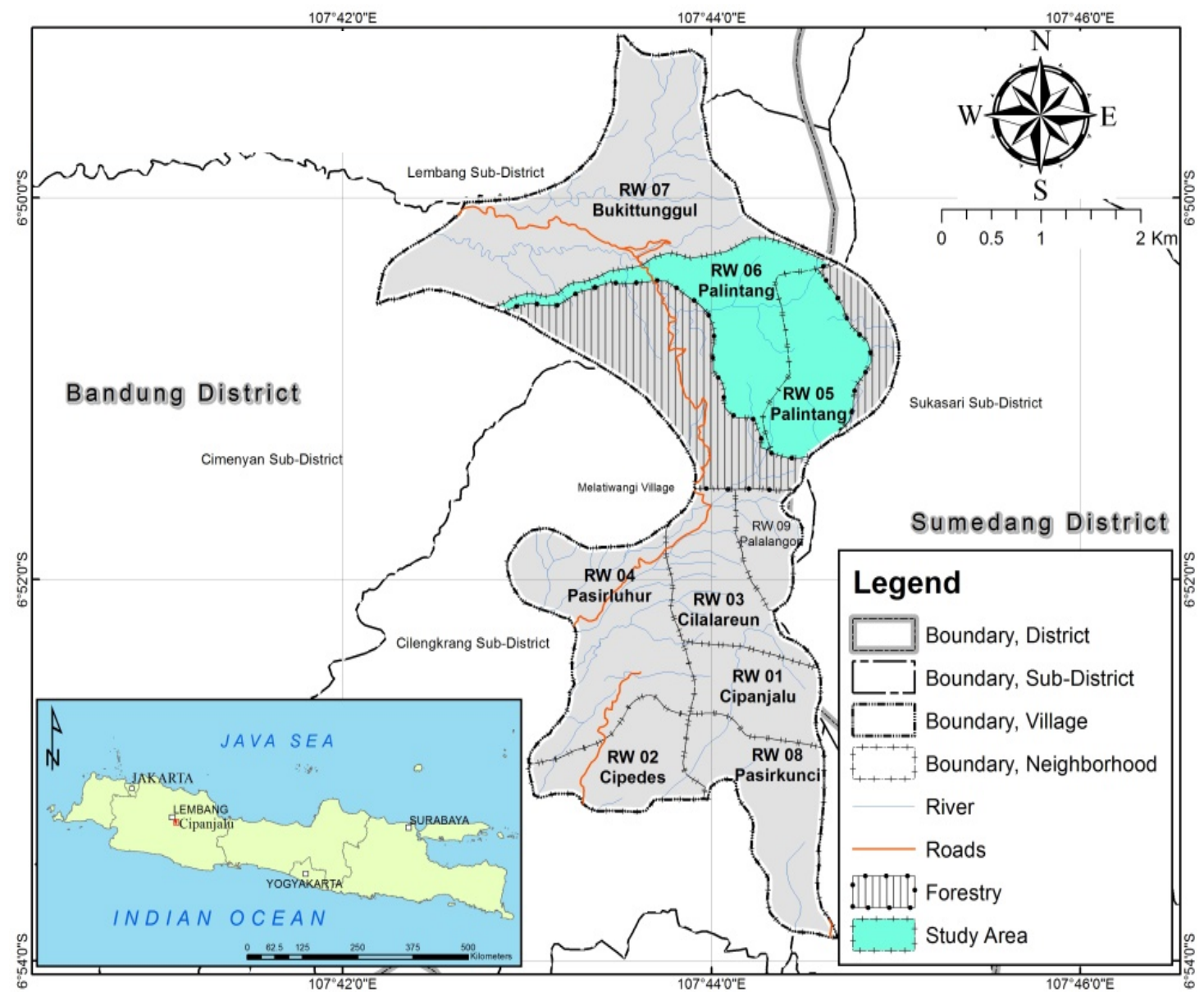

Figure 1. Study site Palintang Hamlet, Cipanjalu Village, Cilengkrang Sub-district, Bandung District, West Java, Indonesia (Iskandar et al. 2017)

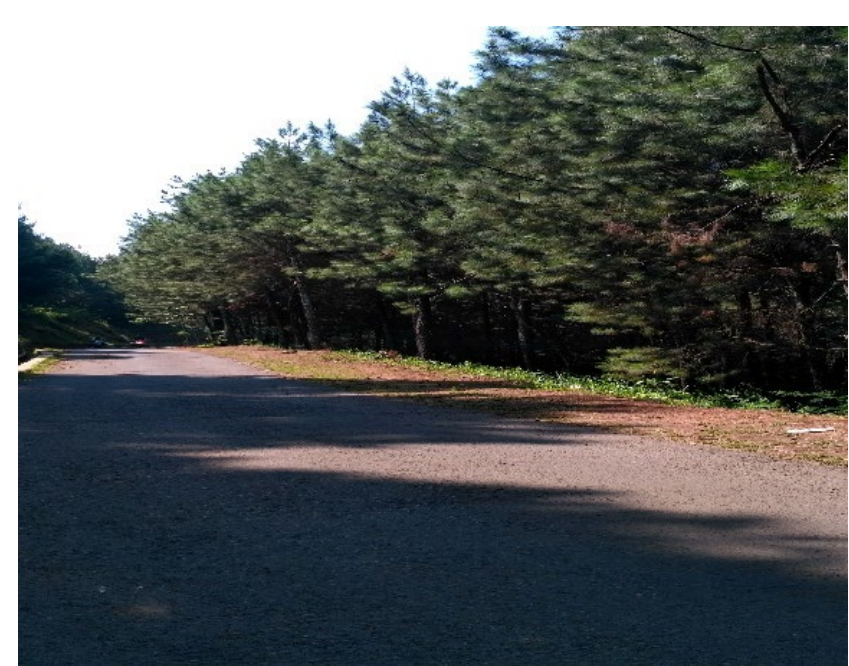

$\mathbf{A}$

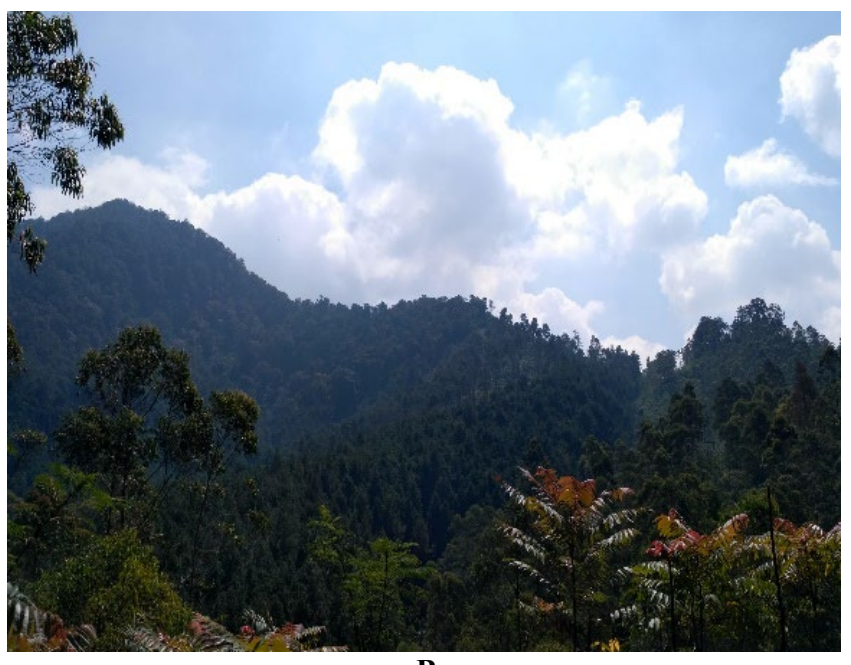

B

Figure 2. A. The main road from Ujung Berung to Palintang hamlet made of asphalt, B. Palintang hamlet has located in the enclave of the forest of pine of Perhutani 
Forest managed by Perhutani surrounds Palintang hamlet. The agricultural land is located in the north of the settlement. In the past, many people predominantly cultivated vegetable in the forest and recent development, vegetable farming has reduced. Formally, cultivation of vegetable crops in the forest was prohibited since 1983 due to its potency to cause environmental destructions, including landslide (Iskandar et al. 2016). Therefore, recently, most people of Palintang are still allowed to cultivate pine forest of Perhutani, with emphasis on the farming of coffee mixed with pine trees. As a result, the coffee has been predominantly farmed in the form of agroforestry system, where the main crop coffee (Coffea arabica L) trees are planted with other annual and perennial crops such as banana, avocado, vegetable crops, which are integrated with pine trees.

Palintang people have predominant Sundanese ethnic, and religion of the majority of people is Muslim. Some traditions, including a traditional ritual of expression of farmers to God for they have succeeded in harvesting various crops and hoping for a condition of wellbeing (selamet). The Palintang people have managed their agricultural system based on a combination of the traditional ecological knowledge (TEK) and Western knowledge called 'hybrid knowledge' (Iskandar and Ellen 2000; 2007).

Traditionally, children of each farmer family have been invited to go to the garden by their parents, so they can learn to farm by looking at practices or being included in the work done by their parents in farming. Regarding formal education, the old generation has predominant formal education only the graduate of elementary $(S D=$ Sekolah Dasar) and junior high school ( $S M P=$ Sekolah Menengah Pertama). Today, however, some young generations have the formal education of graduate of the senior high school or few of them continue their education to college.

\section{Method}

The qualitative method was used in this study to obtain data on social phenomena on adoption coffee plant in the Palintang community. In other words, the qualitative approach was chosen as this research focused on elaborating the practices carried out among Palintang farmers to farm coffee plants in the forest, and to manage the forest environment. Some techniques including observations, semi-structured interviews, and participant observation were applied to collect the primary data in the field (Martin 1995; Newing et al. 2011; Albuerque et al. 2014; Iskandar 2018). The observation was done to observe the environmental conditions of the forest, coffee garden, various activities of farmers in the management of coffee garden and processing of coffee beans post harvesting. Semi-structured interviews were carried out with informants that were purposively selected and using of some guidance of special topics, including ecological history of introduction of coffee plant to Palintang; management of coffee in the forest, including site establishment, land preparation, planting and maintenance, harvesting and post-harvesting, marketing; and benefits of farming coffee in the forest. Informants who have profound knowledge on the introduction of coffee to Palintang and various aspects of coffee cultivation management, processing, and marketing of coffee beans were purposively selected by snowball sampling technique (Koentjaraningrat 1991). Some informants, including members of two main farmers groups, informal and formal leaders, and Perhutani staff were selected.

Meanwhile, the researchers also carried out participant observation, and intensively accompanying the informants in doing their activities as usual while telling what was asked during the interview. In addition, researchers also participated in various levels of informant activities being studied. For example, in one occasion researchers participated with one or more informants in harvesting coffee in the forest, and in another occasion, the researcher also involved with another informant in processing coffee beans post-harvesting in the settlement area.

\section{Data analysis}

Data obtained from observations, semi-structured interviews, and participant observations were mainly documented in the form of the field notebook, and interview transcripts were analyzed by several stages. These included cross-checking, verification, and reduction of the data, then followed by summarizing and synthesizing, and building up a narrative account, in-depth description and interpretation of various situations or topics with descriptive analysis (Miles and Huberman 1992; Newing et al. 2011).

\section{RESULTS AND DISCUSSION}

\section{Introduction of coffee}

Based on ethnobotanical history, coffee (Coffea arabica L) has initially been from Ethiopia (Burkill 1935). Coffee was introduced to Java Island by Dutch Colonial (Burkill 1935; Cramer 1957; Muhsin 2017). Coffee was firstly introduced and tried out in Resident area of Preanger. Furthermore, the planting coffee in Preanger Residence involved a lot of labors and covered large areas. As a result, the production of coffee in Preanger Residence was recorded the highest as compared to that of other residents in Java. Besides, the cultivation of coffee was practiced in the Preanger area for a long time in the period between 1677 and 1870s called the period of 'Preanger Cultivation' (Preanger Stelsel). In 1726 VOC (Vereenigde Oost Indische Compagnie or United East India Company) controlled between $50 \%$ and $75 \%$ of the world's coffee. Most of the production documented almost $75 \%$ of the total from Preanger Residency (Muhsin 2017; Breman 2014).

Firstly, coffee was introduced to Preanger by VOC in the early eighteenth century. Coffee was firstly planted in Preanger in 1707. The motivation of VOC to cultivate coffee in this area was related to the interests of the world coffee market. Coffee cultivation was stable until the midnineteenth century as supported by many factors such as 
suitable soil condition, labor availability, coffee price, the percentage of farming, and supervision. In 1723, almost 2.441.000 coffee trees, 1.041.000 were in the fruiting stage, were found in Preanger. Period of 1830 and early 1840 model of coffee planting was popularly known as 'fence coffee'/'hamlet coffee' (kopi pagar/kopi kampung) and forest coffee. In 1837 in Bandung and Sumedang, West Java, more than $50 \%$ fence coffee and forest coffee, while in Sukapura District more than $63 \%$ was recorded as forest coffee. In 1839, fence coffee or hamlet coffee increased in three districts, namely Bandung, Sumedang, and Sukapura, as high as $55.71 \%, 55.48 \%$, and $53 \%$, respectively.

Unlike previous early periods, in the early $1850 \mathrm{~s}$, coffee was mostly planted in a garden model, indeed for 1857 1868 more than $80 \%$ was recorded as a coffee plantation. Also, the Government developed coffee garden owned by private in Preanger. Government coffee was developed coffee garden held by privates in Preanger. The private businessmen began invested in the coffee plantation in 1870 as the consequence of the application of liberal economic politic at that time. Based on ecological history, from 1830 to 1870 the cultivation system was applied in Java, and after 1870 most forest land was rented for development of private plantation (Geertz 1963). However, in Preanger Residency, the participation of private companies has begun since the nineteenth century, namely the planted coffee trees in private land (Muhsin 2017).

Since the Dutch Colonial, coffee of West Java has been known as 'Java Preanger coffee' because this coffee was firstly planted in Preanger (Dinas Perkebunan of West Java 2016). From interviews, nowadays, Palintang people do not know precisely when coffee was introduced to their area because there was no written document or written history of when coffee was introduced to their area. But they believe that coffee plant has already been grown in their area for a long time since the Dutch Colonial. For example, based on information from one of the informants, an old man, Pak Amin mentioned that coffee grown in his garden has been existing since he was a child and his grandfather was still alive. Pak Amin beliefs that he owns the coffee, and historically, it was initially been inherited from the father of grandfather, and it was initially from the rest of the coffee plantations in the forest during the Dutch colonial era. Like Pak Amin, some informants have also mentioned that coffee has been existing since the Dutch Colonial period. However, it was not clear how many hectares of coffee trees were planted in the Palintang area during the Dutch Colonial because, at that time, quinine plantation was dominant in Palintang and the surrounding areas; the coffee plantation was less well known in this area (Iskandar et al. 2017; Kurniawan et al. 2018).-From environmental history, until the late twentieth-century quinine (Chincona sp) has been cultivated in the Preanger which is very popular in the world as a center of quinine production. Indeed, in 1939, more than $90 \%$ of world demand quinine powder was supplied from some plantation areas of Bandung high-land area (Kurniawan et al. 2018).

After Indonesia independent, the plantation in the forest that was previously managed by the Dutch colonial has been taken over by the Indonesian Government. Moreover, primarily, in Palintang area, the plantation in the forest has been controlled by Perhutani. According to the informants, cultivation of coffee in Palintang hamlet begun since 1984, evidenced, among others, by the existing large coffee trees in this area. However, some trees were cut by farmers for the reason that the price of coffee was only Rp.2000/kg and has not been increased since the 1990s. Until the 2000s, the coffee trees had been planted recorded the least in number. Since then, the coffee cultivation has been paid less attention by most farmers. Consequently, the traditional ecological knowledge of Palintang farmers on coffee cultivation dominantly transmitted by oral using mother language and also by individual experiences in the field, along with time has slowly eroded (cf. Ellen and Harris 2002; Maffi 2004; Lizaralde 2004; Iskandar 2018).

As a result, at that time, many people have preferred to cultivate vegetable crops as its production can be quickly sold for cash to fulfill the household needs. Since most people of Palintang have no enough private land for practicing cultivation, many farmers have cultivated vegetable crops in the forest managed by the Perhutani. For example, as revealed by informants that in the past, people of Palintang have been allowed to grow vegetable crops in the forest. As the forest status was production forest, then the rural people of Palintang were allowed to cultivate vegetable crops through the tumpangsari program of Perhutani (Iskandar et al. 2017). The Tumpangsari program has been known as reforestation system program under which farmers are permitted to plant crops, including vegetable crops between rows of forest species for one to two years. Since this vegetable farming needs full sunshine intensity to get good production, some forest trees covering vegetable crops were cut down.

Moreover, environmental problems including soil erosion and hydrological disorder have been inevitable due to the decrease of the forest coverage. In many cases, the environmental issues have been mainly caused by lousy human behavior on the environment which is caused by the rapid increase of population, the increase of human needs, and market economic development (Iskandar 2014; 2017). Since vegetable farming activities had destructed the forest, the status of the forest of Palintang has been changed from the production forest to protected forest. Consequently, the Palintang farmers were not allowed anymore to do farm vegetable crops in the forest.

The change of forest status has significantly affected Palintang people. For instance, according to informants, the prohibition of planting vegetable crops in the forest caused some people to experience food shortage and no family income. Indeed, the Palintang people have suffered from both food and economic crises. Consequently, from 2002 through 2004, after cultivations of vegetables in the forest was prohibited, some people engaged in collecting woods from the forest for making charcoal to sell to urban areas. This situation worsens the socio-economic conditions of the Palintang people and forest environment. As a result, forests needed attention from stakeholders for revegetation and recovering of its function. Finally, several people assisted by outsiders, including students, proposed to the government on management of natural resource of forest 
based on forest management with the community participant called PHBM (Pengelolaan Sumber Daya Hutan Bersama Masyarakat). Based on this program Perhutani has socialized planting of productive perennial plants such as avocado (Persea americana Mill), jackfruit (Artocarpus heterophyllus Lam), coffee (Coffea arabica L), and banana (Musa x paradisiaca L). As a result, Palintang people have cultivated the coffee in the Perhutani forest since 2005.

In 2005, Perhutani socialized forest rehabilitation program through agroforestry system by planting coffee trees mixed with wood trees, mainly pine trees in the forest. Initially, although Perhutani has socialized the planting of coffee, Palintang people have not enthusiastically adopted the agroforestry program since the coffee trees can only be harvested after at least 3 or 4 years after planting. Whereas, what is needed by Palintang people is the economic turnover as quickly as possible to meet their household daily needs. At the early stage of coffee adoption in Palintang, farmers have planted coffee mixed (tumpangsari) with vegetable crops. At least, this activity is carried out until the first coffee harvest, because after the coffee trees are getting higher, and are ready to bear fruit, the land cannot be planted with vegetable crops anymore due to low sunshine intensity under shading canopy of coffee trees. In addition, planting vegetables can also interfere the coffee growth. Planting of coffee in Palintang has predominantly undertaken in rows under pine (Pinus merkusii (Jungh) et De Vriese) trees in the forest. Farmers perceived that planting coffee by tumpangsari system with pine trees is considered being appropriate, and coffee may grow adequately. After four years planting period, in 2009, coffee trees were first harvested. As coffee farming undertaken by farmers has produced a good yield, many other farmers of Palintang adopted farming coffee in the forest. At first, the price of coffee was less promising, but nowadays, the price of coffee is higher in the market. Consequently, today coffee has predominantly been planted in Perhutani forest of Palintang and can be annually harvested (Figure 3 and Figure 4). This case demonstrates that when local rural people and outside knowledge meet and form the 'hybrid knowledge', the process may generate workable solutions to sustainable problems, including environmental forest problems of Palintang due to intensive planting vegetable crops (cf. Iskandar and Ellen 2007). People of Palintang have adopted cultivation of the coffee and gradually leave the cultivation of vegetable crops in the forest of Perhutani because, historically, they knew about the cultivation of coffee, particularly for old people, and the coffee has mainly provided some economic benefits for the local community (Iskandar and Ellen 2007; Iskandar et al. 2017).

\section{Cultivation of coffee}

In everyday life, humans always make a reciprocal relationship with their environment. Humans, in interacting with their environment or ecosystem such as utilizing and managing plant species and other resources, are influenced by social-cultural system factors and ecological system or ecosystem factors (Iskandar 2018). All of these factors collectively determine the individual's decision to bring natural resources and the environment into effect. Thus, human actions in treating nature and its ecosystem depend on how the individual or community of the population understands or perceives nature or the surrounding ecosystem, which forms the corpus-cosmos-praxis complex system (Carlson and Maffi 2004).

From the interrelationship between social system and the environment, farmers of Palintang have cultivated the forest ecosystem of Perhutani for planting coffee trees based on local knowledge or traditional ecological knowledge and strongly embedded with their culture. Today, Palintang farmers can be divided into several farmers groups called KTH (Kelompok Tani Hutan=Forest Farmer Group). These KTH groups are under the hierarchy level of LMDH (Lembaga Masyarakat Desa Hutan= Forest Village Community Institutions). Farmers of KTH member have farmed kopi Arabica (Coffea arabica L.) which is appropriate with local environmental conditions such as the altitude of approximately 1,400 m above sea level (asl) of Palintang forest. Ecologically, Arabica coffee grows well in regions between 1,000 and 1,500 $\mathrm{m}$ above sea level (asl), while robusta coffee (Coffea robusta L. or synonym Coffea canephora Pierre) appropriately grows in an area between $40 \mathrm{~m}$ asl and $900 \mathrm{~m}$ asl (Hulupi and Martini 2013). For example, some informants mentioned that they have preferred to plant Arabica coffee instead of Robusta coffee because Arabica coffee grows better if planted under shading of other plant canopies. Therefore, this coffee is considered to be appropriate when cultivated under the pine trees of Perhutani forest at Palintang area.

Cultivation of coffee in Palintang forest under PMDH program has been managed by corporation between the rural community of Palintang and Perhutani. The Perhutani provides pine forest land located around Palintang hamlet while farmers cultivated coffee under the pine forest. Initially, Perhutani only offered the land; thus, many farmers wanted some more roles in the program of community forest management of planting coffee. As a result, in a recent development in 2017, Perhutani has provided various assistances for farmers including coffee seeds that are locally called coffee seed of Ateng or acronym of Aceh Tengah (Central Aceh), and some training of the coffee cultivation. However, practically, farmers have predominated managed coffee plantation in the pine forest as they directly practiced planting of coffee over time.

Cultivation of coffee in the forest involves 5 stages, namely land establishment (penetapan lahan), seed preparation (penyiapan benih), planting and maintenance (penanaman dan pemeliharaan), harvesting and post harvesting (pemanenan dan pasca panen), and marketing (pemasaran), which were mainly carried out by farmers of Palintang. 


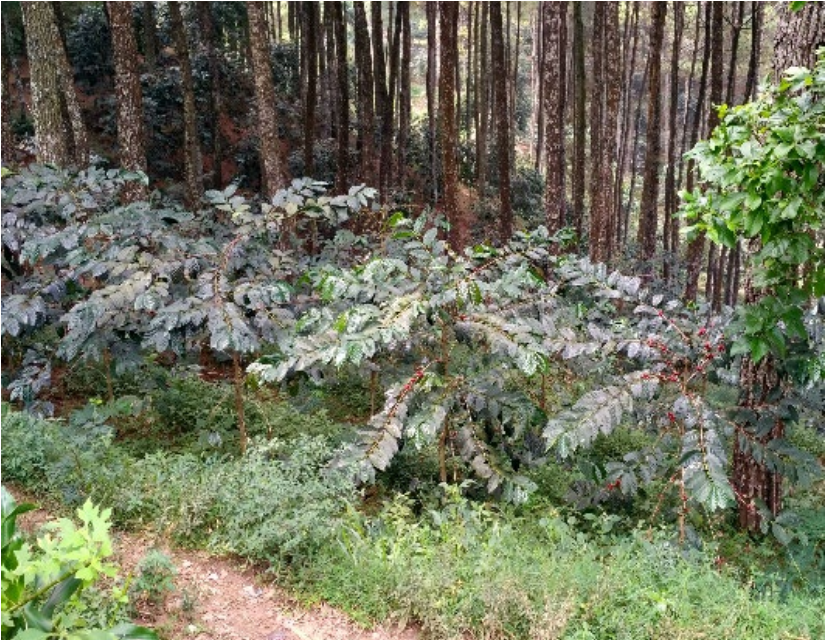

Figure 3. Coffee trees farmed in the pine forest of Perhutani owned by Palintang farmers

\section{Land establishment}

Although coffee trees have been planted in the homegarden, most coffee trees have been more farmed in the forest land of Perhutani. Based on environmental history, the rural people of Palintang hamlet have involved in cultivation system in the forest for a long time. Before the introduction of the tumpangsari program of Perhutani, rural people have traditionally practiced swidden farming (huma) systems (Iskandar et al. 2017). However, they have never been practicing the wet rice farming (sawah) system as most of the land is owned by the government.

In the PHBM program, Perhutani invited the community to farm coffee on the forest land that can benefit the socio-economy of the community and also maintain the forest environment. Until now, however, there are no written regulations for the distribution of land for the people who are growing coffee trees in the Palintang.

One of the informants mentioned that at the beginning of introduction of coffee through PHBM, on behalf of the leader of Forest Farmer Group (KTH=Kelompok Tani Hutan), he (the informant) formally asked Perhutani to be provided with land for planting coffee trees. He was then presented with several hectares of forest land to be planted and also given the task to re-distribute the land to the $\mathrm{KTH}$ members. He mentioned that his group is considered as a formal community institution so that the government has trusted his group in receiving various assistances to be distributed to other farmer groups. Unlike the previous informant, another informant mentioned that the use of Perhutani land for planting coffee trees had been mainly based on an informal agreement between the Perhutani and the local community. In other words, there was no formal letter of agreement to legalize each rural community to cultivate the forest land with coffee trees. Nonetheless, usually the farmers in the community coordinate with each other in choosing the land for growing coffee. After that, the group leader will convey the scope of the land to be planted by his group to other farmer groups.

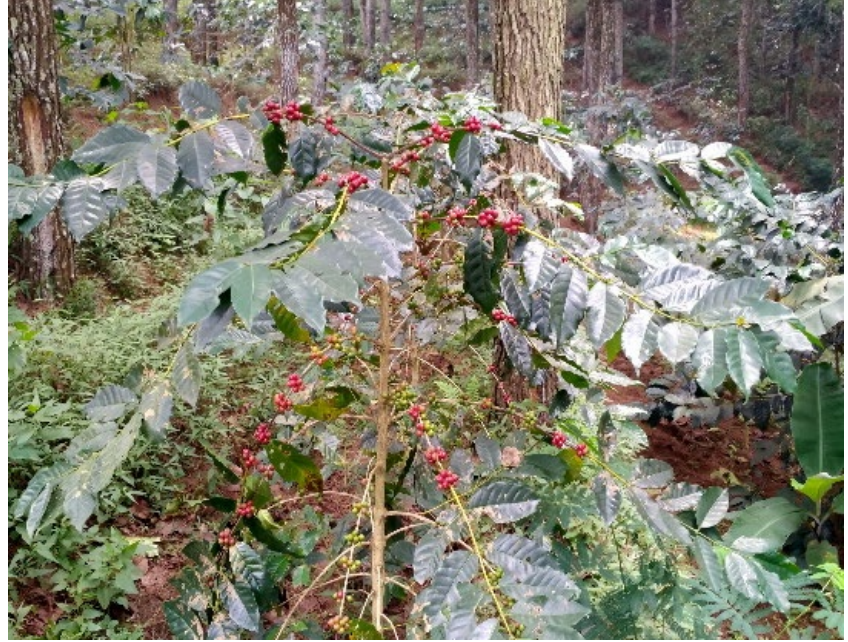

Figure 4. Ripe coffee beans before harvest in the pine forest of Perhutani

Traditionally, the Palintang people have the local knowledge that the suitability of a block of forest land for planting coffee is recognized by local environmental indicators. For example, the forest block identified as fertile land and suitable for planting coffee is indicated by its high humus content and dense shrubs vegetation. Based on Palintang people perception, the ideal planting distance of coffee trees in the plantation is approximately $2-2.5 \mathrm{~m}^{2}$. Based on this planting space, the number of coffee trees going to be planted can be determined, and the farmer will be able to calculate the size of the land needed for planting coffee trees. For example, when a farmer is asked about land size of his coffee garden in the forest, he will answer the question based on the number of coffee trees that he has planted. Amount of coffee trees will vary between one farmer to another, depending on the capital and labor they have. Concerning the capital, for example, planting of 1,000 coffee trees requires cash of approximately between 10 million and 15 million Indonesian rupiah. The number of coffee trees planted by each farmer varies between 500 trees and 2,000 trees depending on the available capital and labor for managing various activities of coffee cultivation.

\section{Seed preparation}

Coffee plantation has been existing in Palintang for a long time. Therefore, most coffee seeds used for re-farming coffee in the forest are recently produced from the from the remnants of the old Dutch coffee trees. Although most farmers have been able to get coffee seeds from Perhutani, the coffee seeds are considered poor in quality. Pehutani has introduced coffee seeds from outside instead of improving local seeds. However, these coffee seeds have not adopted yet to the local environment of Palintang as shown by its poor growth and yield. Farmers perception on the adaptation of coffee on the local environment is very much in line with the Western scientific knowledge (ethic view) that plants growing in a place are influenced by the genetic nature and local environment where they grow (Sastrapadja and Widjaja 2010). 


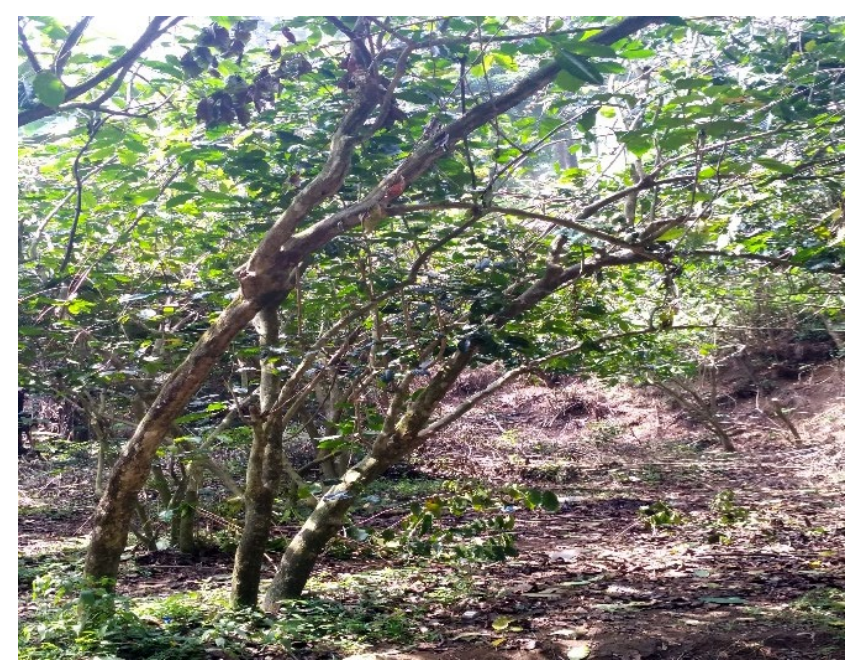

Figure 5. Old coffee trees growing around the settlement area of Palintang hamlet as one of the grafting sources

Some techniques, including transplantation of coffee stem as vegetative regeneration method, have been applied by farmers to prepare the coffee seedlings for cultivation in the forest. Some informants have made coffee seed preparation by transplanting the existing old coffee trees in the surrounding settlement and forest area. Since many old coffee trees are abundantly growing in the surrounding settlement area, the source of seeds for grafting is widely available (Figure 5). In the recent development, however, good quality seeds are also widely used by farmers to grow coffee as a generative regeneration method in the forest. Usually, coffee seeds used for cultivating coffee have been appropriately selected to get good quality seeds.

According to the informants, seedlings are ready to be replanted in the forest at the age of approximately eight months, at the height of about $20 \mathrm{~cm}$ and $40 \mathrm{~cm}$. In the past, many farmers planted a coffee seedling of $20 \mathrm{~cm}$ height which needs a more extended growth period of around four years to be harvested. In addition, the seedlings lower than $20 \mathrm{~cm}$ height can be used for farming with the consequence of high risk of pest attack and diseases to occur and also low sunlight intensity that it can get. Today, because the Palintang farmers have been successful in farming coffee because they were able to integrate local knowledge and Western knowledge provided by the government trough extensions programs

\section{Panting and maintenance}

Land preparation is carried out before planting the coffee seedlings. Initially, the shrubs are manually cut, and the dry twigs and dry leaves of pine trees are removed from the field. Palintang people perceive that forest land to be planted by coffee trees must be cleared from weeds and dry litters consisting of leaves and twigs of pine trees. Since the pine litters have reduced, the $\mathrm{pH}$ soil is considered to be not acid. The coffee can grow well in the less acidic soil of pine forest. As local people, based on Western knowledge or scientific ecological knowledge, in general, soil of the pine forest is usually acid. Therefore, by removing the dried leaves and dry twigs, the surface of the soil under pine canopy will reduce the soil acidity. Coffee is generally quite tolerant to mild acidic soils with $\mathrm{pH}$ around 5-6.5 (Anggarani 2011; Subandi 2011).

After land clearing, farmers prepare planting holes for putting coffee seedling. According to the informants, the size of the planting hole made by Palintang farmers is usually $50 \mathrm{~cm}$ x $50 \mathrm{~cm} \times 50 \mathrm{~cm}$ size. The planting holes are usually prepared around 3 to 5 months before planting to allow it to regulate soil health. Also, farmers are waiting for the seeds to be ready for planting. The planting holes for planting coffee are usually also provided with compost or animal dung to increase soil fertility. When the seedlings meet the ideal height, and the planting hole is ready, then planting is carried out around October to coincide with the beginning of the rainy season.

After coffee seedlings are grown in the planting holes, they are usually controlled at least twice a week to evaluate their growth conditions. The farmers also perform weeding to prevent sunlight competition with weeds and hence to allow the coffee plants to obtain enough sunlight interception. Farmers also occasionally water the newly planted coffee plants to prevent them from drying out due to water shortage. Coffee plants require only moderate fertilization to grow optimally, therefore, the coffee farmers in Palintang usually only provide organic fertilizer such as manure or rely on organic matters such as compost or litter derived from the falling leaves in the forest.

In general, the cultivation of coffee requires more intensive care during the initial phase from seed preparation to planting time. Less intensive care is needed afterward as coffee trees are known to be able to survive under limited water availability and less favorable growing conditions. Maintenance of coffee trees is commonly done by doing weeding to prevent the newly planted coffee trees from competing with weeds for nutrients.

Based on literature, some diseases and pests, including borer usually attract the stem and branches; nematodes attack the roots, and fungi attack leaves, stems, and roots of the coffee plant (Anggarani 2011; Subandi 2011; Hupi and Martini 2013). However, these various diseases and pests have not seriously found in the coffee plants of Palintang farmers. Thus, synthetic pesticides have intensively been used for vegetable farming instead of applying it in coffee farming.

When coffee plants have grown tall and began to bear fruit, maintenance of coffee trees has been limited only to weeding. Fertilizers and irrigation of coffee plants are only provided once in a year. In general, Palintang farmers let coffee trees to grow tall and have many branches. The farmers generally do not cut the branches of the coffee tree for the reason that coffee can produce a lot of fruits and maximum with many branches (Figure 6). However, after obtaining new information or knowledge from outside and shared among local farmers, nowadays some coffee farmers of Palintang have started to do pruning of coffee tree for a better yield (Figure 7). Today, they have conducted the standard best practice of coffee cultivation where the branches are usually pruned to get some positive benefits such as more healthy trees, easily coffee tree maintenance and harvest, better airflow in the canopy, more effective pest control, and also avoiding excessive but poor fruits (Hulupi and Martini 2013). 


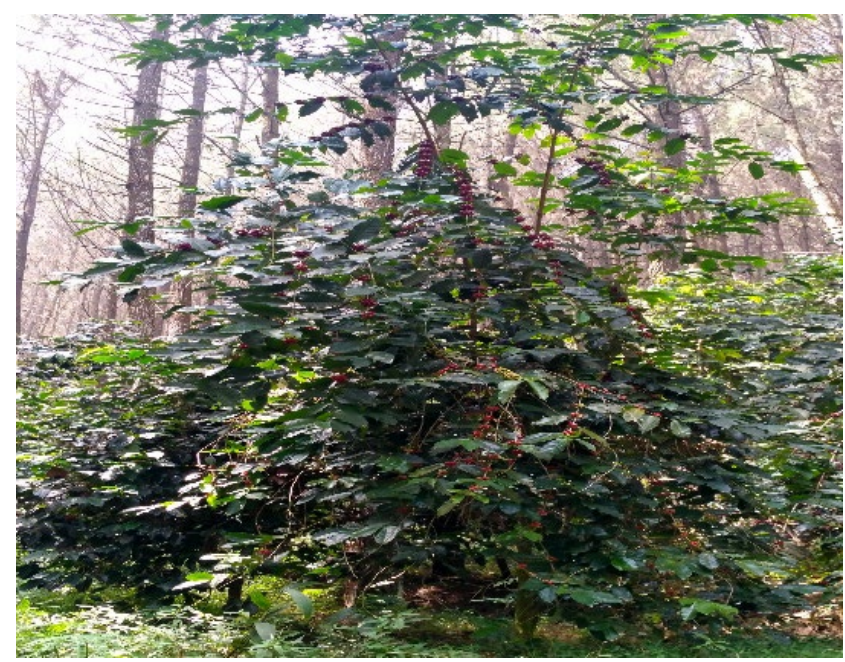

Figure 6. The coffee tree without pruning

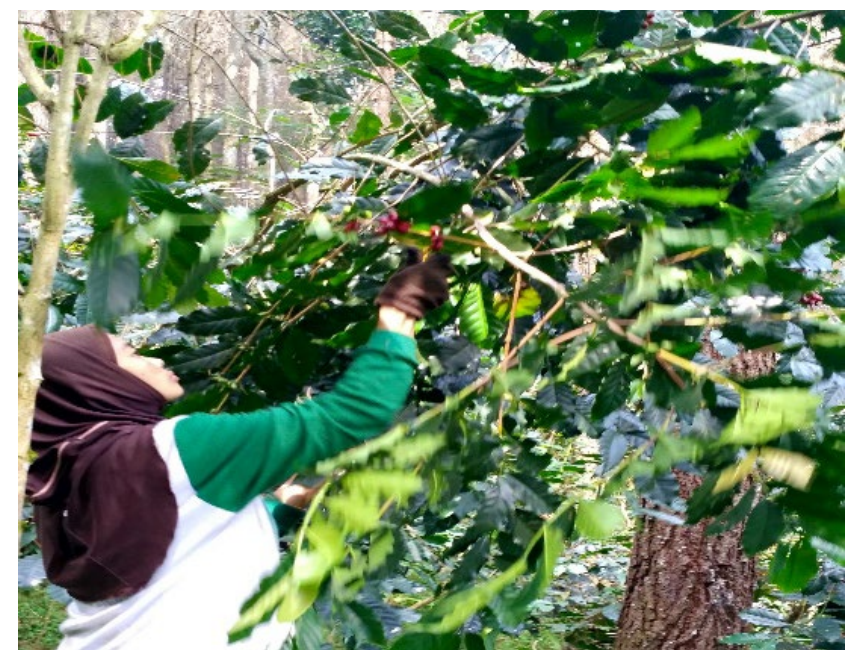

Figure 8. A female labor is harvesting coffee beans

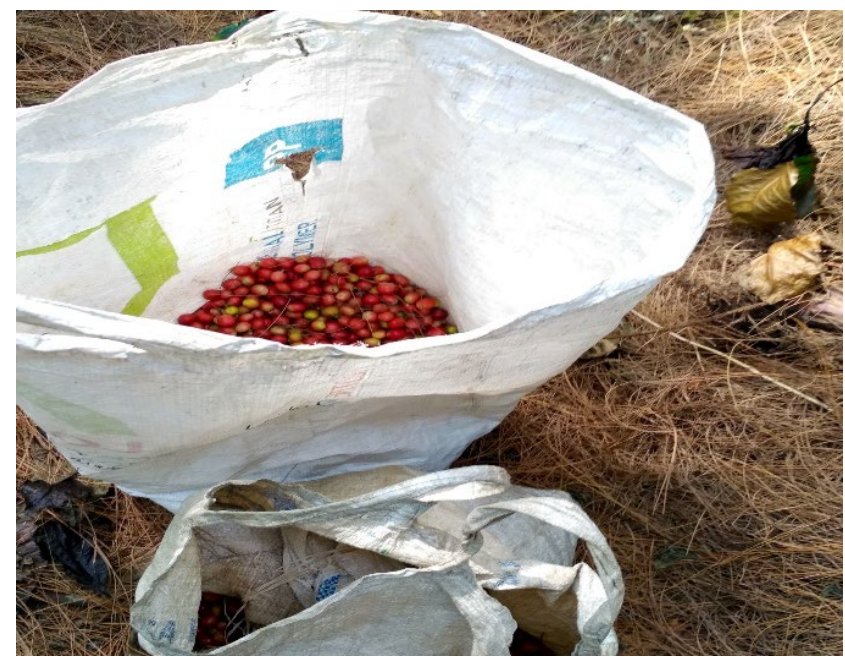

Figure 10. Fresh coffee beans have just been harvested and put into a sack

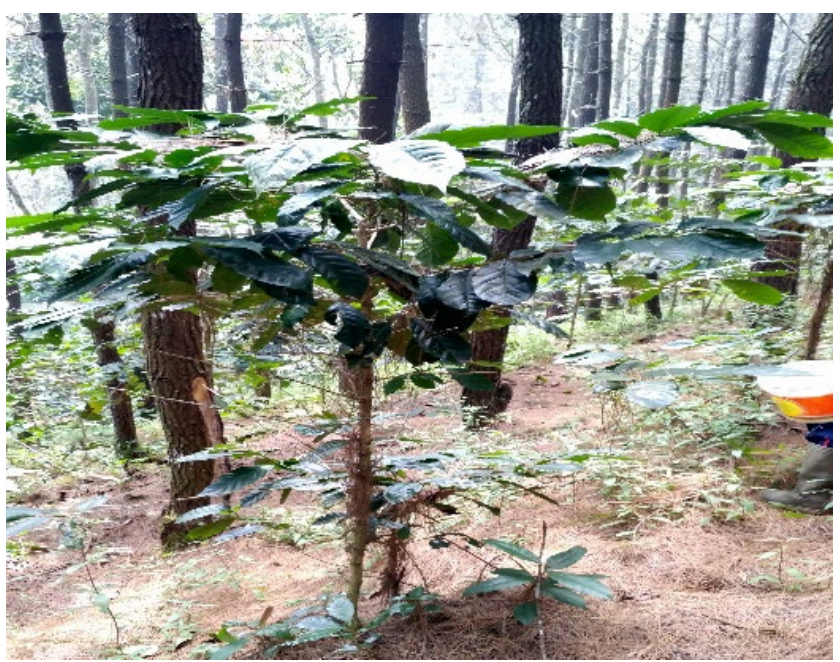

Figure 7. The coffee trees that are pruned

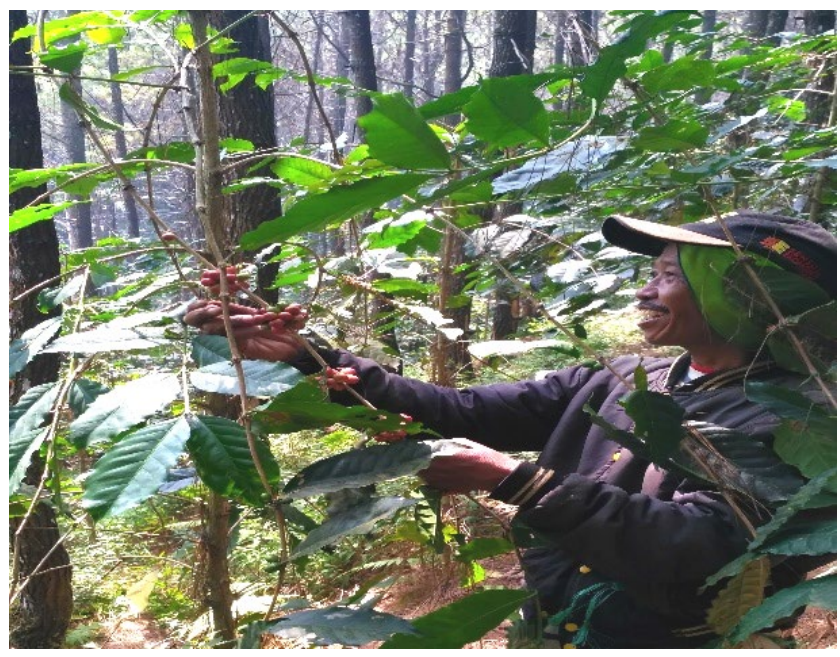

Figure 9. A male farmer, as the coffee owner, is harvesting coffee beans

\section{Harvesting and post-harvesting}

Coffee trees planted in the pine forest of Perhutani of Palintang started to yield at the age of approximately three years old but the coffee beans produced at this age is in low yield. Usually, coffee trees produce maximal beans at about seven years old. The coffee beans are generally harvested each year. Palintang farmers usually harvest the coffee beans between June and September and peak season of harvesting is generally carried out between July and August. The harvesting of coffee beans is usually done several times with a maximum of nine times depending on the number of trees planted in the forest.

Harvesting of coffee beans during the non-peak season is mainly undertaken by family labor. Farmers having more than one hectare of coffee plantation requires additional labor forces for harvesting. The labor costs for picking the coffee fruit were recorded about Rp. 2,000/kg fresh fruit in 2008. Harvesting of coffee beans is usually undertaken from 6.00 a.m. to 2.00 p.m. with an approximate harvest 
about $20 \mathrm{~kg}$ and $40 \mathrm{~kg}$ coffee beans, or at maximum of 65 $\mathrm{kg}$ for skilled labors. Most hired workers for coffee harvesting are female labors (Figure 8) while transport of harvested coffee beans from the forest to settlement is mainly carried out by male workers. Some coffee plantation owners do the harvest themselves or employed male labors for harvesting the coffee beans (Figure 9), most notably in the case that they do not have too many coffee trees, and the location of the coffee trees in the forest is only in one area as it is more cost efficient.

The fresh coffee beans harvested from the agroforestry system of the pine forest of Perhutani are brought to the settlement area. Those coffee beans are commonly sold to a leader of farmer group of forest farmer as a local middleman. Most farmers sell their coffee bean in fresh that is locally called 'cherry'. Palintang farmers mainly sell cherry coffee instead of the dried coffee beans because they need immediate cash for the household income and daily necessities, including foods (Figure 10).

In addition, if the coffee beans are processed first, such as the shells are peeled or commonly called seedless coffee beans (gabah), it requires large capital to buy a peeler machine and also energy to wash shell-less coffee beans and to dry them. If the owner first processes the coffee beans, there is a lot of time allocated for processing the coffee, thus, time allocated for harvesting the rest of the coffee that in the coffee garden is becoming more limited. In general, the coffee harvest is usually conducted in a few months. Women usually do coffee processing.

Coffee beans of the farmers are usually purchased and accommodated by several heads of forest farmer groups. In 2018 the price of 'cherry' in the Palintang ranged between Rp. 8,000 and Rp. $9,000 / \mathrm{kg}$. The price was not fixed depending on the selling price of coffee at the national level. Meanwhile, coffee production in Palintang was approximately $3 \mathrm{~kg} /$ tree, and if a farmer planted minimum 1,000 trees in one block of one hectare in the forest, he would get $3 \times 1,000 \mathrm{~kg}=3$ tons of coffee (cherry). So, if the cherry was sold at Rp. 9,000/kg, then from 1,000 coffee trees a farmer could get a gross income of approximately
Rp. 27,000,000. This number could change depending on the individual number of coffee trees planted in one block since one block of approximately one hectare is normally planted with approximately 1,000-2,000 coffee trees. Several farmers also owned more than one block in different forest places with more than 2,000 coffee trees. On the other hand, the results could be lower due to, among others, weather and climatic anomaly. For example, during the study in 2018, coffee production in the Palintang was less than optimal due to the rain that occur when the coffee flowered, which caused the coffee flowers to fall out and the number of fruits decreased.

The coffee beans collected by the local middlemen are processed in several types of wet coffee processing: full wash, semi-wash; honey process, and natural process. Every kind of coffee processing produces different coffee flavor characters and coffee prices. The skills of the farmers in processing coffee were obtained from the training provided by the students and the government officers.

Full wash processing technique is the processing of fresh coffee fruit to become dry coffee beans following several stages of washing. Firstly, the coffee fruit is put in a tub of water to select the best quality coffee fruits (Figure 11). Secondly, coffee fruits are soaked in water. The ripened coffee fruits will sink into the water while the immature ones will float on the water surface. Thirdly, coffee beans are separated from the fruits using a machine locally called 'pulper machine'. Although the coffee beans have been separated, some of them still have un-removed shells. Thus, further fermentation and washing process is needed to allow the fruits become soft, and the coffee fruits and coffee beans become easily separated.

Fourthly, the peeled coffee beans are then fermented for approximately 12 hours or overnight. Fifthly, the coffee beans are then rewashed until the sticky mucus disappeared and continued with drying the coffee beans for about 4 hours under sunlight to reduce water content; these coffee beans are called 'gabah' by Palintang farmers (Figure 12).

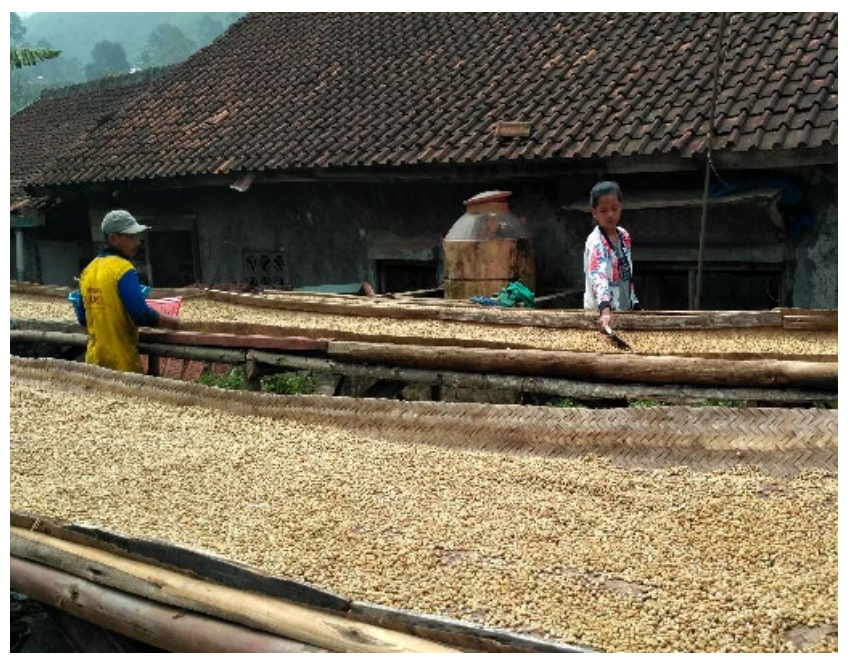

Figure 12. The peeled coffee beans are being dried on a kind of bamboo mat

Figure 11. Women are selecting the coffee beans. 


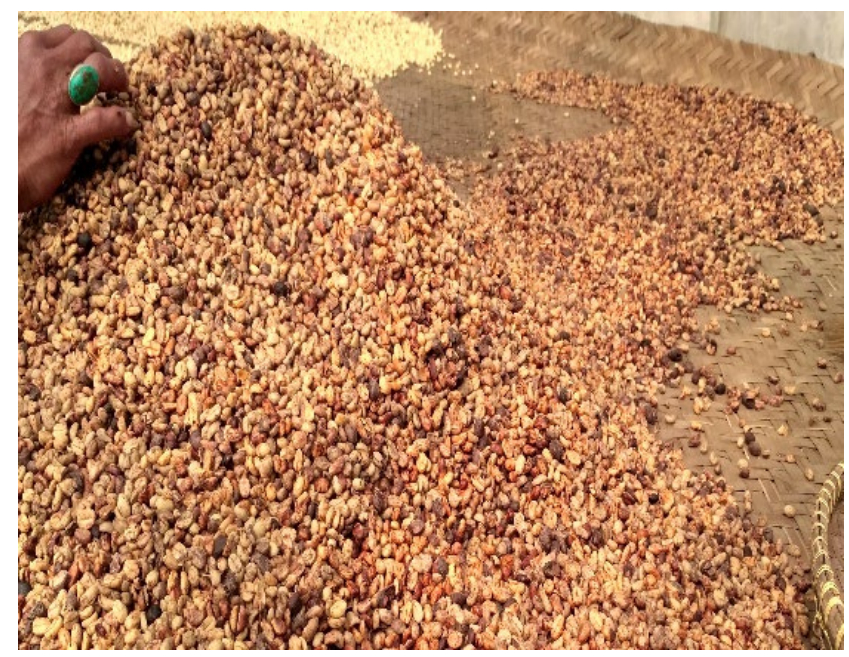

Figure 13. The peeled coffee beans are being dried by direct sunlight

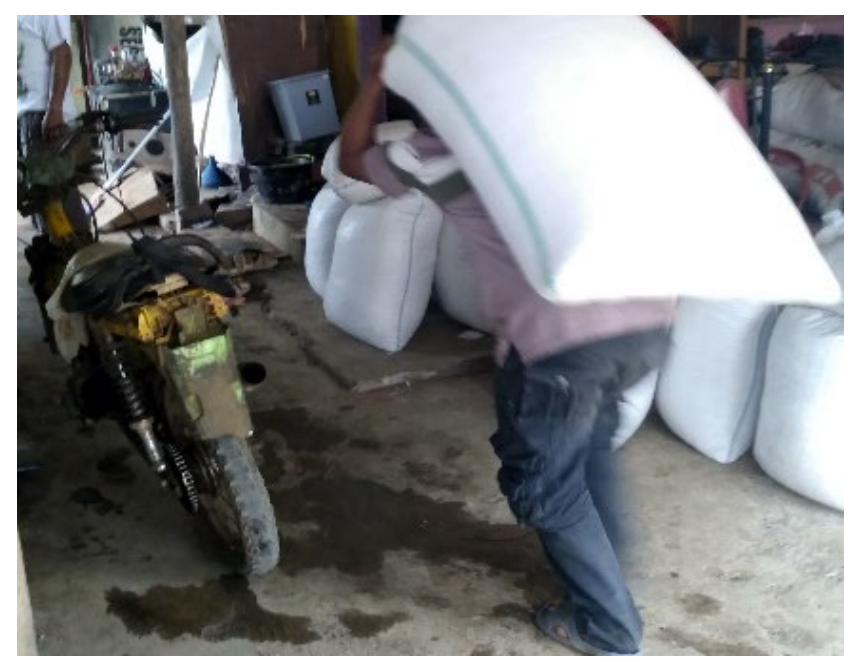

Figure 15. A farmer is storing the coffee beans in the collector place of Palintang

The semi-wash processing technique is almost the same as the full wash technique, but the washing stage uses less water than the full-wash method. Meanwhile, in the honey process processing technique, the coffee fruit is peeled and dried with the mucus layer unwashed (Figure 13). It is called the honey process because when dried the mucus that is still attached to the coffee bean will become sticky and has a honey-like texture. The number of farmers who conducted the honey process is less than those who applied full wash or semi-full wash techniques because the process takes time.

Natural processing techniques are also referred to as dry processing techniques because the coffee fruits are dried with the skin being unpeeled. This process takes a longer time so that the coffee dries perfectly. Even though the price of coffee produced by this processing technique is a higher price than those of other methods, not all middlemen

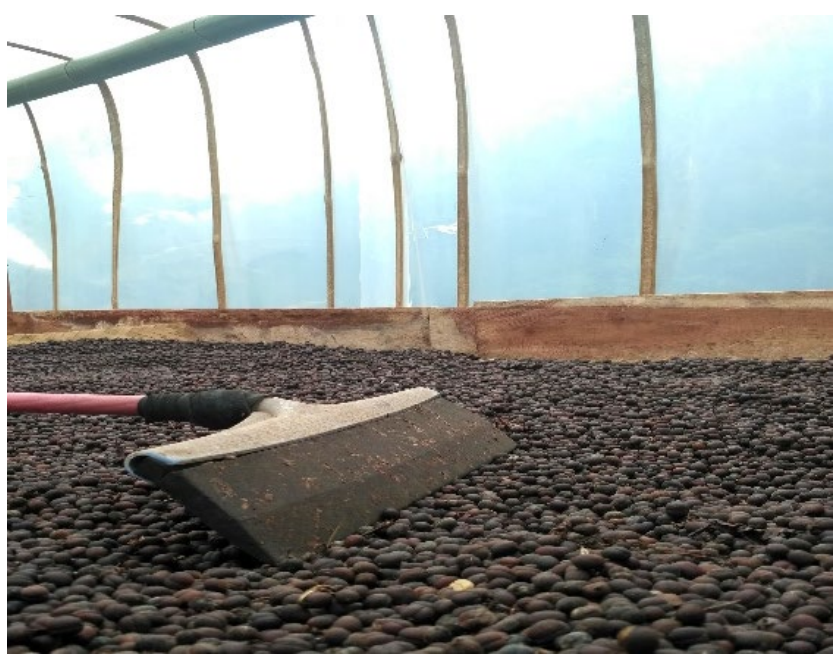

Figure 14. The unpeeled coffee is being dried in the traditional greenhouse

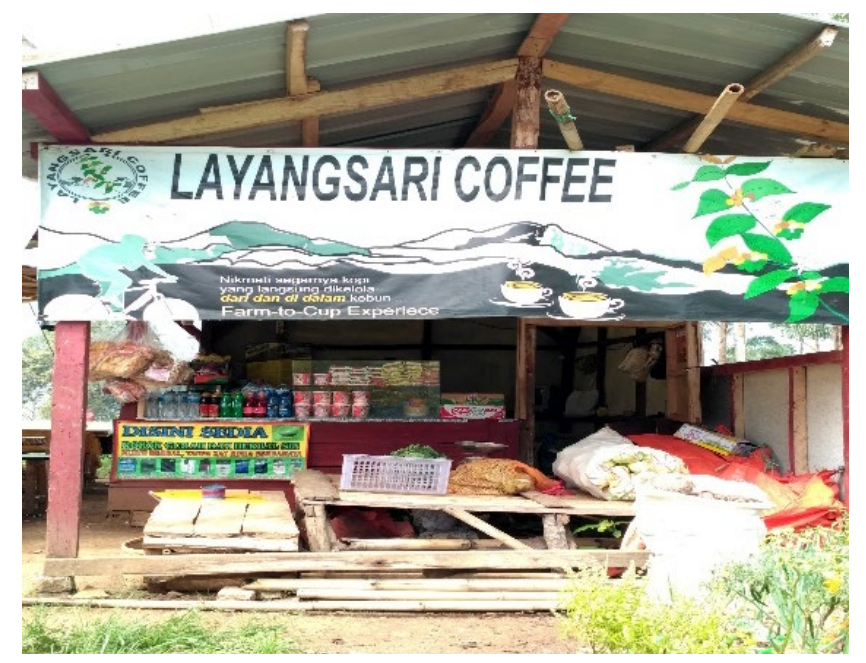

Figure 16. Coffee in the packages are being sold in small shops of Palintang

do this process due to its longer processing time. Coffee processing techniques are also carried out in a greenhouse to prevent contact with direct sunlight (Figure 14).

\section{Marketing system}

Each collector or a leader of a farmer group as middleman has its own way to market the coffee beans. Most coffee beans in Palintang is sold in the form of peeled coffee beans or gabah as required by the market (factories or larger companies). Consequently, 'gabah' sales are higher and faster than processed coffee sales. For example, there are two coffee collectors or middlemen in Palintang that usually sell ' $g a b a h$ ' to coffee agents in Medan. Then, the gabah is sold again by the agents to larger companies such as Starbucks.

In Indonesia, there are two large coffee agents, i.e., in Medan and Surabaya. Coffee agents in Medan mainly buy 
Arabica coffee while coffee agents in Surabaya usually buy Robusta coffee. In 20018, gabah coffee beans in Palintang were sold at price of Rp. 27,000 - Rp. 30,000/kg.

The selling price of coffee is usually adjusted to the national coffee price. The amount of coffee collected by a collector (local middleman) of Palintang during the harvest is usually stored in a special place (Figure 15), amounting to 6 tons per shipment. The collector can send coffee twice in a week.

The coffees collected by the local middlemen in the Palintang were mainly produced by farmers of the Palintang and also from the surrounding areas. Coffee are sold in various forms including gabah, dried or green beans, and roasted and brewed beans that were usually sold, respectively, to middlemen, small coffee shops (kedai kopi), and small snack shop, (Figure 16). In 2018, the gabah beans, roasted packaged coffee, and brewed coffee were sold at a price of, respectively, Rp 200,000/ kg, Rp 400,000/100 gram, and Rp 10,000/cup.

As the Palintang farmers cultivated coffee in the forest land of Perhutani, then the coffee fruits harvested from the forest must be shared with Perhutani. The percentage of coffee production sharing is $70 \%$ for farmers and $30 \%$ for Perhutani. The distribution of coffee production is usually done when the harvest is over and is organized by the head of the farmer group. The members of farmer group usually report their coffee harvest to the group leader. Often, there is one group member who is given the task to record coffee yield harvested from each farmer in the farmer group.

\section{Benefits of farming coffee trees in the forest}

Coffee cultivation in the Perhutani forest area through the Community Forest Resources Management (PHBM) program has been running for ten years which resulted in the Perhutani's forests being covered by wood trees and also economic benefits to the local people of Palintang through the selling of coffee beans. Nowadays, Palintang people have also increasingly been aware that what was done before planting vegetables in Perhutani's forest is not good for forest function sustainability. The socialization from Perhutani regarding the PHBM model has also given awareness of the role played by Palintang people in protecting the forest.

Palintang community claimed that the dense green forest allows them to get cash to buy food (leuweung hejo, rakyat ngejo). They understand that the forest is a place where they can grow coffee to support their families. Their awareness is shown by their concrete actions to voluntarily plant pine trees so that the forest is no longer spares. Some people conducted this action as a redemption of past wrongdoing with illegal logging of timber during the economic crisis in the Palintang since early 1998. One informant, for example, said that "he used to cut down trees to get money to buy food, and now he has to replant the forest by planting trees again."

Another reason for local people to plant wood trees voluntarily is that the coffee plants planted in good forest vegetation conditions produced good coffee yield since coffee plants need shading trees to prevent direct sunlight.
In addition, agroforestry system of coffee cultivation in pine forest of Perhutani has also been considered as an essential role for ecosystem services, such as habitat of wildlife, including birds, pollinator insects, soil invertebrates, and carbon storage and sequestration (cf. Calvo and Blacke 1998; Jones et al. 2002; Denu et al. 2016; Withaningsih et al. 2018; Rodriguesa et al. 2018; Anand et al. 2008). This study revealed that introduction of coffee by Perhutani had been adopted and managed by local community of Palintang based on combination of local knowledge and western knowledge ('hybrid knowledge') through training by outsiders as it can provide socio-economic benefits without disturbing the cultural identity of the local people (cf. Iskandar and Ellen 2000; 2007; Iskandar et al. 2017).

It can be concluded that the local people have positively responded the coffee cultivation in the agroforestry system introduced by Perhutani through the PHBM. Several factors caused the Palintang people to accept coffee plants to be cultivated in forest land, i.e., the coffee plants were only once planted in the past in their area, and the area is suitable for coffee cultivation. Also, the coffee has provided ecological and economic benefits. Regarding ecological benefits, coffee trees can be planted in mixture cropping with fruits, including avocado and banana, and wood trees in the forms of agroforestry system. In the Palintang case, in the early stage of the coffee introduction in the forest, the coffee trees were initially planted in mixture with vegetables. As a result, the farmers still get production from vegetables before the coffee trees produced fruits and were harvested. After the coffee trees were harvested; however, the vegetables farming was gradually reduced and will be ceased shortly because the farmers will mainly get the household income from the coffee production instead of vegetable crop production. Concerning ecological function, by the development of agroforestry of coffee in the forest, forest environments, including soil erosion protection and hydrological function can be maintained. The forest ecosystem of Palintang can be utilized and maintained by the rural community as shown by their perception of the forest ecosystem. Thus, people of Palintang have increased their awareness to protect forest areas owing to the fact the coffee plantation provides economic benefits to them.

\section{ACKNOWLEDGEMENTS}

The research was funded by the ALG (Academic Leadership) Program of Prof. Johan Iskandar under research on Ethnobiology for public welfare to support sustainable development. We are grateful to Rector of Padjadjaran University, Prof. Dr. Tri Hanggono Achmad for providing financial support through the research grant of ALG Program We would also like to thank the village and hamlet leader, Perhutani staff, and all informants who assisted and helped us to conduct this research in Palintang hamlet, Cipanjalu village, Bandung district, West Java, Indonesia. 


\section{REFERENCES}

Albuquerque UP, Fernandes LV, de Lucena RFP, Alves RRN. 2014. Methods and techniques in ethnobiology and ethnoecology. Springer, New York.

Anand MO, Krishnaswamy J, Das A. 2008. Proximity to forests driver bird conservation value of coffee plantations: implication for certification. Ecol Appl 18 (7):1754-1763.

Anggarani ET. 2011. Suitability Evaluation for Coffee Plants in Bulu District, Temanggung Regency. [Hon. Thesis], Department Geography, Faculty of Social Science, Malang State University, Malang.

Breman J. 2014. Colonial advantages from forced labor: Priangan system of cultivation system of coffee in Java 1720-1870. Yayasan Pustaka Obor Indonesia, Jakarta. [Indonesian].

Burkill IH. 1935. A Dictionary of the economic product of the Malay Peninsula. Crown Agents for The Colonies \& Millbann, London.

Calvo L, Blacke J. 1998. Bird diversity and abundance on two different shade coffee plantations in Guatemala. Bird Conserv Intl 8: 297-308.

Carlson JS, Maffi L. 2004. Introduction: ethnobotany and conservation of biological diversity. In: Carlson TJS, Maffi L. (ed), Ethnobotany and Conservation of Biocultural Diversity. The New York Botanical Garden Press, New York.

Cramer JS. 1957. A review of literature of coffee research in Indonesia. SIC Editorial, Inter-American Institute of Agriculture Science, Turrialba, Costa Rica.

Denu D, Platts PJ, Kelbessa E, Gole TW, Marchant R. 2016. The role of traditional coffee management in forest conservation and carbon storage in Jimma Highlands, Ethiopia. Forests, Trees and Livelihood, University of York, UK.

Ellen RF, Harris H. 2000. Introduction. In Ellen RF, Parkes P, Bicker A. (eds.). Indigenous environmental knowledge and its transformation: critical anthropological perspective. Hardwood Academic Publishers, Amsterdam.

Elson RE. 1994. Village Java under the cultivation system 1830-1870 Allen and Uwin, Sydney.

Finesso GM. 2018. Tea of Citarum for the world. In Wawa JE. (ed), 2018 Expedition of Citarum. PT Kompas Media Nusantara, Jakarta [Indonesian]

Geertz C. 1963. Agricultural involution: the process of ecological change in Indonesia. University of California Press, Berkeley, CA.

Hasan A, Amaliah I, Riani W. 2018. The people's coffee business empowerment model in Pangalengan village, Rancakalong SubDistrict, Sumedang District. Prosiding Ilmu Ekonomi 4 (1):9-16. [Indonesian].

Hulupi R, Martini E. 2013. Guidelines for cultivation and maintenance of coffee plants in a mixed garden. World Agroforestry Center (ICRAF), Bogor. [Indonesian].

Iskandar BS, Iskandar J, Irawan B, Partasasmita R. 2018. Traditional markets and diversity of edible plant trading: case study in Ujung Berung, Bandung, West Java, Indonesia. Biodiversitas 19 (2):437452.

Iskandar BS, Iskandar J, Wibawa HA, Partasasmita R. 2017. Farmers and tumpangsari: case study in Palintang hamlet, Cipanjalu village, Bandung, Indonesia. Biodiversitas 18 (3): 1135-1149.

Iskandar J, Iskandar BS, Partasasmita R. 2017. Introduction Paraserainthes falcataria in the traditional agroforestry 'huma' in Karangwangi village, Cianjur, West Java, Indonesia. Biodiversitas 18 (1): 295-303

Iskandar J, Ellen R. 2000. The contribution of Paraserianthes (Albizia) falcataria to sustainable swidden management among the Baduy of West Java. Human Ecol 28 (1): 1-17.

Iskandar J, Ellen R. 2007. Innovation, 'hybrid' knowledge and the conservation of relict rainforest in upland Banten. In Ellen R. (ed) modern crises and traditional strategies: local knowledge in Island Southeast Asia. Berghahn Books, New York.
Iskandar J. 1998. Swidden Cultivation as a Form of Cultural Identity: The Baduy Case. [Disssertation]. University of Kent at Canterbury, England.

Iskandar J. 2014. Human and environment and various changes. Graha Ilmu, Yogyakarta [Indonesian].

Iskandar J. 2017. Human ecology and sustainable development. Environmental Science Postgraduate Program, Padjadjaran University, Bandung. [Indonesian].

Iskandar J. 2018. Ethnobiology, ethnoecology, and sustainable development. Plantaxia, Yogyakarta [Indonesian].

Jones J, Ramoni-Perzzi P, Carruthers EH, Robertson RJ 2002. Species composition of bird communities in shade coffee plantations in Venezuealan Andes. Ornithologia Neotropical 13: 397-412.

Kartasubrata J. 1986. People Participation in Management and Utilization of Forest in Java: Study on Social Forestry in Forest areas of Production, Protection Forest and Conservation. [Dissertation]. Bogor Agricultural University, Bogor [Indonesian].

Koentjaraningrat. 1991. Community Research Methods. Gramedia Pusataka Utama, Jakarta [Indonesian].

Kurniawan M, Finesso GM, Wawa JE. 2018. The history of quinine was eroded from the Preanger stelsel. In Wawa JE. (ed.). Citarum Expedition: A Million Charms and Issues of a Journalistic Report of Kompas. PT Gramedia, Jakarta [Indonesian].

Maffi L. 2004. Maintaining and restoring biocultural diversity: the evolution of a role diversity for Ethnobiology. In Carlson TJS, Maffi L. (ed), Ethnobotany and conservation of biocultural diversity. The New York Botanical Garden Press, Bronx, NY.

Muhsin M. 2017. Priangan coffee production in the 19th century. Paramita: Historical Studies J 27 (2):182-194.

Newing H, Eagle C, Puri R, Watson CW. 2011. Conducting Research in Conservation: A Social Science Perspective. Routledge, London.

Perfecto I, Vandermeer J, Philpott SM. 2014. Complex ecological interaction in coffee agroecosystem. Ann Rev Ecol Syst 45: 137158.

Perum Perhutani. 1994. Experiences of Perum Perhutani in the implementation of social practice in Java. In Simon H, Hartadi, S Sabarudin, Sumardi, H Iswantoro (eds.). Social Forestry and Sustainable Forest Management. Perum Perhutani Jakarta.

Plantation Agency of West Java. 2016. Introducing Java preanger arabica coffee (KJP) who has been protected by geographical indications. Dinas Perkebunan Jawa Barat, Bandung. [Indonesian]

Rodriguesa P, Shumia G, Dorresteijna I, Schultnera J, Hanspacha J, Hylanderb K, Senbetac F, Fischer J. 2018. Coffee management and the conservation of forest bird diversity in southwestern Ethiopia. Biol Conserv 217:131-139.

Sastrapradja SD, Widjaja EA. 2010. Agricultural biodiversity guarantees food sovereignty. LIPI Press, Jakarta [Indonesian].

Soemarwoto O, Soemarwoto I. 1984. The Javanese rural ecosystem. In: Rambo AT, Sajise PE. (eds.). An Introduction to Human Ecology Research on Agricultural Systems in Southeast Asia. East-West Center, Hawaii.

Subandi HM. 2011. Cultivation plant plantation (part of the coffee plant). Gunung Djati Press, Bandung [Indonesian].

Valencia V, West P, Sterling E, Gracia-Barrios L, Naeem S. 2015. The use of farmers knowledge in coffee agroforestry management: implications for the conservation of tree biodiversity. Ecosphere 6 (7): 122. DOI: 10.1890/ES14-00428.1

Widianingsih Y. 2006. The contribution of management of coffee under standing in the PHBM program for household income in BKPH of Pulosari village, Pangalengan, KPH of South Bandung. [Hon. Thesis]. Department of Forest Management, Faculty of Forestry, Bogor Agricultural University, Bogor.

Withaningsih S. Andari CA, Parikesit, Fitriani N. 2018. The effects of understory plants on pollinators visitation in coffee in West Bandung District, West Java, Indonesia. Biodiversitas 19 (2): 604-612. 